\title{
The Relationship Between Family's Affective Functions and Cyberbullying in Adolescents
}

\author{
Laili Nur Hidayati ${ }^{1, *}$ Rizki Afita Oktafianti ${ }^{2}$ \\ ${ }^{1,2}$ School of Nursing, Faculty of Medicine and Health Sciences, Universitas Muhammadiyah Yogyakarta \\ ${ }^{*}$ Corresponding author. Email: laili.ln36@gmail.com
}

\begin{abstract}
Excessive use of the internet in adolescents can raise the risk of violence in cyberspace (cyberbullying). The impact of cyberbullying can range from depression to suicide and can reduce achievement levels at school. Adolescents who commit cyberbullying are caused by a lack of communication and affection in the family. Giving high affection and good communication encourages adolescents to behave positively and avoid cyberbullying behaviors. This study aims to identify the relationship between a family's affective function and cyberbullying behavior in adolescents. This study used a cross-sectional research approach. It utilized a total sampling technique with a total sample of 92 respondents who committed cyberbullying. The instruments used in this study included respondent characteristics, family characteristics, cyberbullying behavior questionnaire, and family's affective function questionnaire. The results showed that the level of cyberbullying of respondents, which was in the low category, was 84 respondents $(91.30 \%)$, while the family's affective function, which was in the high category, was 70 respondents (76.10\%). Spearman Rho analysis obtained p-value 0.818 ( $\mathrm{p}>0.05$ ). Based on the result of this study, it can be concluded that there is no relationship between the family's affective function and cyberbullying behavior in adolescents. It means that we have to respect another function family too. Adolescents and families are advised to spend more time together to improve communication and avoid cyberbullying behavior.
\end{abstract}

Keywords: Adolescents, Cyberbullying behaviour, Family's affective function

\section{INTRODUCTION}

All people, especially adolescents, need technology in modern times. According to a survey conducted by the Indonesian Internet Network Providers Association (APJII) in 2017 [1], 75.50\% of the highest internet users in Indonesia are adolescents aged 13-18 years. Technology that is rapidly developing has not been spared from the impact. Adolescents who use the internet excessively can pose a risk of violence both physically and mentally. Violence can occur to adolescents both at home and outside the home, either in the real-world or in cyberspace. One of the frequent violence in cyberspace is cyberbullying [2].

Cyberbullying is an act that is the same as bullying in general, namely intimidating, mocking, or disturbing others, but it is done via the internet or cyberspace [3]. According to the National Commission on Violence against Women (2016) states that cyberbullying in Indonesia has reached 98 cases, and some of the victims of cyberbullying are female teenagers. In 2016, 51\% of Indonesian adolescents aged 1315 years had been victims of cyberbullying, and this figure is predicted to increase every year under the increasing number of internet usage [4].

Adolescents who experience and do cyberbully occur in adolescents who have low family interactions [5]. Intense communication will improve function in the family, which will lead teenagers to avoid cyberbullying behavior. One of the essential family functions is the affective function [5].

The affective function of the family is a function that is meeting psychosocial needs, such as affection, which is the foundation of family strength [5]. The affective function of the family that works sufficiently will have a role in developing the child's personality. Parents who share adequate love and provide education about the values of life will have a good impact, such as being ready for the child to become the right person. Good behavior will strengthen the mind and mentality of adolescents against what is being faced, including the methods used by adolescents when they face cyberbullying [6].

Based on the results of a preliminary survey conducted by researchers with counseling guidance teachers $(B K)$ and public relations at a high school in Yogyakarta, almost all students were already accustomed to actions such as talking dirty in the school and taunting friends by using animal names either on purpose or as a joke. One of the school policies to prevent bullying is to make anti-bullying posters on school celebration.

In addition, based on the results of a preliminary survey conducted by a high school in Yogyakarta among ten students 
from each batch, 8 out of 10 students stated that they had commented on someone's photo and sent harsh words on social media either by on purpose or accidentally. The results of the interview also showed that 3 out of 10 students did not live with their parents since they were working outside the city, and they were not native residents of Yogyakarta. Apart from not living with their parents, they said that their parents still lacked affection and only gave something in material form.

Seeing the high number of internet use in Indonesia, which can have an impact on cyberbullying behavior in adolescents, and the importance of family affective function, researchers are interested in examining the relationship between family affective function and cyberbullying behavior in adolescents.

\section{METHODS}

This research is a quantitative study using a descriptive correlational design with a cross-sectional method that held in one of senior high school at Yogyakarta, Indonesia. Ninety-two respondents were taken who committed to behaving cyberbullying. The research instrument used a cyberbullying behavior questionnaire and the questionnaire of family affective function. The result of validity cyberbullying behavior questionnaire is $0,369-0,825$ and reliability test is 0,923 . Then, for family affective function has validity $0,398-0,779$ and reliablity 0,847 .

The respondents completed the questionnaire individually during class time. Before participating in this research, the respondents were told that the questionnaire response would be done voluntarily, they were allowed to stop responding to the questions anytime, and there were no correct or wrong answers. Moreover, the responses would be treated confidentially. The headteacher initially gave consent to the student's involvement in the research. Outlined letters containing the nature of research were sent to the parents of the students, and they were ensured to have received the information. Parents were asked to contact the school if they did not want their son/daughter to participate in the study.

\section{RESULT}

\subsection{Respondent Characteristics}

Table 1 illustrates that the characteristics of respondents based on gender are mostly male with a total number of 63 respondents $(68.48 \%)$, and most of them being 16 years old of 44 respondents $(47.83 \%)$, while the highest frequency of internet usage is 5-6 hours with a total of 31 respondents $(33.70 \%)$. The present study employed 92 respondents who were selected based on age, gender, and frequency of internet usage.

\subsection{Family Characteristics}

Table 2 shows that family characteristics based on

Table 1. Respondent Characteristics

\begin{tabular}{|l|l|c|c|}
\hline \multicolumn{2}{|c|}{$\begin{array}{c}\text { Respondent } \\
\text { Characteristics }\end{array}$} & $n$ & $\%$ \\
\hline \multirow{4}{*}{ Age } & 15 years & 20 & 21,74 \\
\cline { 2 - 4 } & 16 years & 44 & 47,83 \\
\cline { 2 - 4 } & 17 years & 22 & 23,91 \\
\cline { 2 - 4 } & 18 years & 6 & 6,52 \\
\cline { 2 - 4 } & Total & 92 & 100 \\
\hline \multirow{4}{*}{ Gender } & Male & 63 & 68,48 \\
\cline { 2 - 4 } Internet & Female & 29 & 31,52 \\
\cline { 2 - 4 } Usage & Total & 92 & 100 \\
\cline { 2 - 4 } & $<1$ Hour & 4 & 4,35 \\
\cline { 2 - 4 } & $1-2$ hours & 12 & 13,04 \\
\cline { 2 - 4 } & $3-4$ hours & 28 & 30,43 \\
\cline { 2 - 4 } & $5-6$ hours & 31 & 33,70 \\
\cline { 2 - 4 } & $\geq 7$ hours & 17 & 18,48 \\
\cline { 2 - 4 } & Total & 92 & 100 \\
\hline
\end{tabular}

maternal age are 46-60 years old among 75 respondents $(81.52 \%)$, with family members of $4-5$ people in 70 respondents $(76.10 \%)$. While the highest economic status of the family, whose income is more than or equal to the regional minimum wage (UMK) in Yogyakarta, is seen among 58 respondents $(63.04 \%)$.

Table 2. Family Characteristics

\begin{tabular}{|c|c|c|c|}
\hline \multicolumn{2}{|c|}{ Family Characteristics } & $n$ & $\%$ \\
\hline \multirow{3}{*}{$\begin{array}{l}\text { Maternal } \\
\text { Age }\end{array}$} & $30-45$ years & 17 & 18,48 \\
\hline & $46-60$ years & 75 & 81,52 \\
\hline & Total & 92 & 100 \\
\hline \multirow{4}{*}{$\begin{array}{l}\text { Number of } \\
\text { Family } \\
\text { Members }\end{array}$} & 3 people & 15 & 16,30 \\
\hline & 4-5 people & 70 & 76,10 \\
\hline & $>5$ people & 7 & 7,60 \\
\hline & Total & 92 & 100 \\
\hline \multirow{3}{*}{$\begin{array}{c}\text { Family } \\
\text { Economic } \\
\text { Status }\end{array}$} & $\begin{array}{c}\text { Income } \\
\geq \mathrm{Rp} \mathrm{1.709.150;}\end{array}$ & 58 & 63,04 \\
\hline & $\begin{array}{c}\text { Income } \\
<\text { Rp 1.709.150; }\end{array}$ & 34 & 36,96 \\
\hline & Total & 92 & 100 \\
\hline
\end{tabular}




\subsection{Cyberbullying Behaviour}

Table 3 illustrates that the distribution of cyberbullying behavior is mostly captured in the low category, with a total of 84 respondents $(91.30 \%)$. Cyberbullying behavior in this study is used to determine the level of cyberbullying behavior that occurs in each respondent.

Table 3. Cyberbullying Behavior

\begin{tabular}{|l|c|c|c|}
\hline \multicolumn{2}{|c|}{ Category } & $n$ & $\%$ \\
\hline \multirow{3}{*}{$\begin{array}{l}\text { Cyberbullying } \\
\text { behavior }\end{array}$} & Low & 84 & 91,30 \\
\cline { 2 - 4 } & Moderate & 8 & 8,70 \\
\cline { 2 - 4 } & Hlgh & 0 & 0 \\
\cline { 2 - 4 } & Total & 92 & 100 \\
\hline
\end{tabular}

\subsection{Affective Function of Family}

Table 4 shows that the highest family affective function is in the high category, with a total of 70 respondents $(76.10 \%)$. Family affective function in the present study is used to determine the level of affective function of the family that exists in each respondent.

Table 4. Affective Function of Family

\begin{tabular}{|c|c|c|c|}
\hline \multicolumn{2}{|c|}{ Category } & $n$ & $\%$ \\
\hline Affective & Low & 0 & 0 \\
\cline { 2 - 4 } $\begin{array}{c}\text { Function of } \\
\text { Family }\end{array}$ & Moderate & 22 & 23,90 \\
\cline { 2 - 4 } & Hlgh & 70 & 76,10 \\
\cline { 2 - 4 } & Total & 92 & 100 \\
\hline
\end{tabular}

\subsection{Relationship between Affective Function of the Family with Cyberbullying Behaviour}

This study was conducted to discover whether there is a relationship between the affective function of the family cyberbullying behavior to respondents.

Based on the table 5, shows that respondents who behave cyberbullying in the low category have a high family affective function with 63 respondents and medium affective function with 16 respondents with a value of $\mathrm{p}>0.05$. By having $\mathrm{p}-$ value $=0.818$, which means that there is no relationship between the affective function of the family with cyberbullying behavior in adolescents. The correlation value is 0.024 , where $r$ is $0.00-1999$, so that the interpretation is fragile, and the direction of the correlation is positive. It means that the higher the affective function of the family, the lower the cyberbullying behavior.
Table 5. Relationship between Affective Function of the Family with Cyberbullying Behavior

\begin{tabular}{|l|c|c|c|c|c|c|}
\hline \multirow{2}{*}{ Variable } & \multicolumn{2}{|c|}{ Cyberbullying behavior } & \multirow{2}{*}{$n$} & p-value \\
\cline { 2 - 6 } & Low & Moderate & High & & \\
\hline $\begin{array}{l}\text { Affective } \\
\text { Function } \\
\text { of }\end{array}$ & High & 63 & 10 & 0 & 73 & \\
\cline { 2 - 6 } & Moderate & 16 & 3 & 0 & 19 & \multirow{2}{*}{0,818} \\
\cline { 2 - 6 } & Low & 0 & 0 & 0 & 0 & \\
\cline { 2 - 6 } & Total & 79 & 13 & 0 & 92 & \\
\hline
\end{tabular}

\section{DISCUSSION}

\subsection{Characteristic of Respondent}

\subsubsection{Age}

The results of this study indicate that the majority of respondents who experience cyberbullying are adolescents aged 16 years. It is because, at this age, adolescents demand to try new things and have a feeling of being free in doing various things so that it is difficult to control various activities. This result is in line with the study conducted by Rachmatan and Ayunizar [7], which states that adolescents aged 16 years have the highest level as suspect (a person who commits cyberbullying) of cyberbullying and in the age of 15 years have the lowest score. This age occupies the highest number since, at this age, adolescents are in the middle adolescent stage, where they prefer to try new things. This result is not in line with the research of Putri and Putra [8], which stated that the suspect of cyberbullying were mostly teenagers aged 15 years, while for 16 years old were ranked second. It is because adolescents at the age of 15 are very easy to engage in aggressive behavior, such as disturbing others to seek pleasure. Adolescents aged 13 or 14 years - 17 years are adolescents with developmental stages that have achieved many changes, including emotional imbalance [9]. Middle adolescents aged 15-18 have experienced an increase in thinking skills and awareness to cope with stress and experienced emotional increases. It can result in adolescents who are likely to be prone to depression, anger, unable to control emotions, which in turn can cause problems for them [10].

Therefore we can see that adolescence is very influential in cyberbullying behavior. In the results of the study, adolescents aged 16 years are more likely to engage in cyberbullying behavior because adolescents are more likely to experience difficulties in controlling their emotions so that it can cause cyberbullying problems and the desire of adolescents to try new things

\subsubsection{Gender}

Males are more likely to be cyberbullying suspects because they enjoy traditional bullying, and it is possible for cyberbullying to occur whenever they feel their problem has not been resolved and are dissatisfied with the previous bullying. The results of the present study are in line with Rahayu's research [2], which states that males are more 
frequently the cyberbullying suspect because they are often involved in traditional bullying. Moreover, bullying is then extended to the virtual world, especially when traditional bullying is no longer used. The results of Satalina's research [11] showed different results than female gender engaged in cyberbullying behavior more often because women preferred to tell stories, and when they felt upset, they were easier to vent their frustration through cyberspace or directly.

According to research by Sartana and Afriyeni [12], which are in line with previous journals, males are more often to become the suspect of cyberbullying. A total of 46 male respondents and 30 female respondents who performed cyberbullying. Males have more potential to do cyberbullying because they are often involved in traditional bullying. They prefer to conceal their feelings so that they will probably perform cyberbullying by venturing the feelings directly or through cyberspace.

\subsubsection{Frequency of internet usage}

The results of the present study indicate that the highest frequency in using the internet among respondents is between 5 - 6 hours. The use of the internet for 5-6 hours has a negative impact because it will cause a decrease in learning achievement among adolescents. Also, they rarely socialize outside because they use smartphones too often. The results of the present study are in line with the research conducted by Ikhsani and Rakhmawati [13], which states that using the internet for more than 6 hours will have an impact on decreasing learning achievement and increasing the incidence of cyberbullying behavior. Since adolescents usually use the internet for more than 6 hours just to release boredom or seek entertainment and lack of supervision from parents and closest relative, this can lead to cyberbullying behavior. The results of the research by Sartana and Afriyeni [12] show different results from the present study, where most of the respondents who behave cyberbullying are adolescents who use the internet for 4 hours. Adolescents who use the internet for 4 hours and act in cyberbullying will have an increased risk of adolescents experiencing academic problems. After all, they will tend to have difficulty concentrating, lower grades, and a higher rate of absence from school because they spend more time with smartphones.

Internet usage for 6 or 4 hours both entails adverse effects. Excessive internet use is one of the determinants that can lead to cyberbullying behavior in modern times, especially when there is a lack of supervision from parents and the people surrounding it. It is because various groups very much need the use of the internet, both adults, adolescents, and children, to make life easier today.

\subsection{Characteristic of Family}

\subsubsection{Maternal Age}

The results of the present study indicate that the age of the mothers of the respondents is aged $46-60$ years. Maternal age in the range of 41-60 years is in the middle age adult category, which is characterized by physical changes (gray hair, the skin begins to shrink and begins to decrease in visual acuity) and emotional changes (marked by being wiser in doing things). This thoughtful attitude is in the form of awareness to share what is needed by his family. The attitude also arises because someone in middle-aged adults has realized that life must be more useful before the productive periods [14].

The results of the present study are in accordance with Meilasari's [15] research. The age of mothers aged 41-50 years often gives affection to existing family members because, at that age, the mother is more capable and accustomed to sharing roles and affection at home.

Mothers who are categorized in the middle age adults act as the primary caregivers of adolescents and are more responsible for their duties. In being the primary caregiver for adolescents, mothers play a significant role in improving adolescent behavior, from good practice to lousy behavior and improving adolescent socialization whenever issues arise. When mothers are no longer nurturing their children, adolescents will behave aggressively, violently, and have a terrible impact, which will lead to cyberbullying behavior [16].

So it can be concluded that adolescents who have mothers in the middle adult category (41-60 years) who are not responsible for their duties and give up their role as child caregivers will cause adolescents to behave aggressively and allow cyberbullying behavior to emerge.

\subsubsection{Number of Family members}

The results of the present study indicate that the number of family members is mostly to have 4-5 people, with a total of 70 respondents. A family consisting of father, mother, and children (brother/sister) who live in the same place that has excellent communication between family members will form a positive adolescent personality [17]. It is because when a connection is intensely established, trust, honesty, and openness are created between family members, and leads to a good response in the form of behavior and action (Gunarsa, 2004) [17].

Excellent communication will bring out family harmony. Adolescents who are raised in a harmonious family will have positive behavior. Meanwhile, adolescents who are raised in unharmonious families such as broken homes, bad interpersonal relationships between family members, and lack of time between family members will put them at risk of experiencing personality disorders. If left untreated, this personality disorder will develop into adolescents with antisocial personality and deviant behavior, which can lead to cyberbullying behavior [17].

Family members and a large number of siblings (ranging from 4-5 people) will allow adolescents to get lots of affection from all family members. Adolescents who have siblings can be used as supervisors in daily youth activities, especially in cyberspace. Adolescents who have the oldest sibling are more reliable because they understand more information written online and are willing to share their experiences than their parents, and thus they will be able to provide more protection for their siblings online. The attention 
given to siblings will give a sense of comfort to adolescents, and adolescents will feel happy because they have a partner to share and complain about the problems they face. Therefore, they keep adolescents away from juvenile delinquency, violent behavior, and even cyberbullying [18].

So it can be concluded that adolescents who live with large family members and are raised by a complete family and have excellent communication between family members will result in adolescents having good behavior and personality. Adolescents will feel the affection given by all family members, so adolescents will not seek affection outside their family so that it can reduce the number of cyberbullying incidents in adolescents.

\subsubsection{Family economic status}

The results of the present study indicate that the economic status of the respondent's family is more than or equal to the regional minimum wages in Yogyakarta ( $\geq$ IDR 1,709,150), with a total of 58 respondents. The results of the present study are consistent with the research of Indrawati [19], which explains that a high level of economy (> IDR 1,500,000 per month) can affect the intensity of communication in a family. Economic status has a meaning that shows the family's ability to meet the needs and material equipment they have. The financial situation of the family can improve communication because the family will spend more time together so that communication is established. Communication that occurs intensely can build a relationship of intimacy and closeness between parents and their children so that the love needed by children is fulfilled.

Low economic status is also a determining factor for cyberbullying because a low economy allows adolescents to seek what they need and demand outside of their family due to the limitations and difficulties of their parents in fulfilling their wishes. Unfulfilled adolescent desires will result in adolescents committing juvenile delinquency, bullying, and even cyberbullying to convey resentment because their desires are not achieved [18].

High family economic status is measured by the success of both parents at work and the parents' level of education. The education level of parents is also a factor that determines the economic status of the family. Education has a vital role in an individual's ability to hone his skills, which makes one is ready to get the job he wants to increase the family income. A prestigious position is a result of an educational achievement made by parents [20].

Apart from education, occupation also affects the economic status of the family. According to Dewi and Basti [21], mothers who work and have their income can provide the love needed by their children and their families. It is evidenced by the number of adolescents who expressed satisfaction with the condition of their mothers who have careers when mothers can divide their time between family and work. Adolescents stated that working mothers could meet their needs, can give a lot of attention to their families, and can be intense and persistent personal examples for their children. Working mothers who can give their children time between their busy schedules will provide a well-established closeness and positive feelings to each other.
So it can be concluded that education and occupation of parents are factors that can improve the economic status of a family. Higher education will make it easier for individuals to find and determine jobs to improve their economic status. High economic status can improve communication because the family will spend time together so that communication is well-established. Good communication will build intimacy and closeness between parents and their children so that the love needed by children is fulfilled and reduces the number of cyberbullying,

\subsection{Cyberbullying Behaviour}

The results of the present study indicate that the cyberbullying behavior of the respondents is in a low category, reaching up to 84 respondents. Cyberbullying suspects usually do this because they think that friends who are victims will not be angry or feel offended. [22] The low level of cyberbullying in Yogyakarta High School can be caused by a form of bullying prevention carried out by schools by making anti-bullying posters. Teachers consider that bullying or cyberbullying that occurs at school can harm adolescents.

The actions taken by schools are following the research of Dominguez, Franco, and Hueros [23], which stated that teachers could prevent cyberbullying in various ways. Teachers strengthen the role of counseling teachers, provide lessons about anti-cyberbullying and character-building. Also, they increase parental involvement in adolescent activities. Parents must understand the dangers of cyberbullying so that parents can be warned about the consequences of cyberbullying.

Prevention of cyberbullying can also be carried out by nurses in the school domain, especially community nurses, where they play a role and carry out their responsibilities in primary health care efforts, which focus on promoting and preventing cyberbullying behavior in adolescents [24].

\subsection{Family Affective Function}

The results of the present study indicate that the family affective functions in the respondents are considered high, with a total of 70 respondents. Having a high affective family function enables the family to create good relationships between family members. Almost all families in the respondent have given love, respect, mutual support, and adolescents have adequate time to build and spend with family [6]. According to Susanti's research, [5] families that provide love, respect, and care with one another will have a positive impact on family members and especially adolescents.

Adolescents who experience cyberbullying at a low level are teenagers with families who carry out their functions sufficiently. Some of the family functions assessed are in the form of communication between family members and parenting styles adopted by parents. Excellent family 
communication can affect the self-concept of adolescents in the family, as well as the support and affection of their parents. Whereas in families whose functions do not work well, it will contribute to vulnerability in adolescents and increase the incidence of cyberbullying due to lack of family support for adolescents and the lack of family ability to solve problems [25]. Communication and support in the family is an essential key in the running of the functions that exist within the family, especially the affective function. Good communication and support provided by the family will increase a good self-concept in adolescents while living their lives.

\subsection{Relationship between Affective Function of The Family with Cyberbullying Behaviour}

Based on the results of the hypothesis test, the significance or $p=0.818$ ( $p>0.05)$, which means that there is no relationship between family affective function and cyberbullying behavior in adolescents. The correlation value is 0.024 , where $r$ is in the range of $0.00-0.199$ so that the interpretation is very weak, and the direction of the correlation is positive. It means that the higher the affective function of the family, the lower the cyberbullying behavior. The affective function of the family only has a slight influence on cyberbullying behavior, while the rest is influenced by other factors because other variables such as adolescent self-control that researchers cannot control, while what researchers can control is the school climate. The results of the present study are in line with research by Mursafitri, Herlina, and Safri [25], which states that the higher the affective function of the family, the lower the juvenile delinquency will be. It is because adolescents assume that they are cared for by their parents to obtain the love they need. Also, according to Novrian [6], it is stated that when the function of the family is implemented well and is at a high level, the tendency for youthful bullying behavior will be lower.

Other factors that can influence cyberbullying behavior in adolescents include adolescent self-control and school climate [27]. Self-control is a factor that cannot be controlled by researchers because this factor comes from within adolescents. Low adolescent self-control will increase cyberbullying behavior. Self-control is related to the ability of adolescents to control their thoughts and behavior in everyday life. When adolescents have a problem and are unable to control their thoughts and behave aggressively, it will cause problems in controlling emotions, which can lead to violence in the future. This violence can occur both in the real world and cyberspace. Aggression in adolescents is an attitude that arises because of the desire from within the adolescent to defend himself from competition and demands to show strength in dominating other students [28].

According to Kowalski, Giumetti, Schroeder, and Lattaner [29], the school climate also affects cyberbullying behavior in adolescents. It is because the school climate is closely related to feelings of trust in all people involved in the school. An unfriendly school environment can make adolescents experience frustration and discomfort in carrying out learning activities and discomfort to the surrounding environment. When adolescents experience frustration, students tend to take aggressive actions either directly or through cyberspace.
The school environment is a place to study, seek academic skills, as well as for social interaction between existing school members. One of the efforts made by the Government in improving and utilizing the school environment is by implementing the full-day school program. Full-day school is conducted in 7-8 hours per day, which aims to reduce juvenile delinquency caused by inappropriate adolescent associations and improve adolescent academic skills. The existence of a full-day school is considered very profitable because adolescents will have more learning time. However, a full-day school program also had another impact, which resulted in adolescents having less interaction with the family environment, which leads to reduced time spent with family, as well as resulting in reduced communication and feelings of less affection from their families [30].

The results of the present study indicate that there is no influence between affective function in the family on cyberbullying behavior among adolescents. It is because several other factors cannot be controlled by researchers, such as adolescent self-control. While the factor that the researchers can control is the school climate, this is because the school climate is also related to the school's efforts to prevent cyberbullying by making posters that cause cyberbullying in the school to be in a low category.

\section{CONCLUSION}

The conclusion for this research in characteristics of adolescents show that most of their cyberbullying levels are in a low category. Most of the characteristics of the family have a high affective function of the family. The results showed that there was no relationship between affective function in the family and cyberbullying behavior on adolescents. It means that the higher the affective function of the family, has the lower the cyberbullying behavior

\section{AUTHORS' CONTRIBUTIONS}

The Community nurses can understand that cyberbullying is a phenomenon that often occurs recently, so it is hoped that nurses can implement preventive action so that cyberbullying does not occur continuously. Schools can strengthen the role of counseling teachers in schools, provide lessons on the importance of anti-cyberbullying and teach youth character development, as well as increase the involvement of parents in supervising adolescents' activities.

\section{ACKNOWLEDGMENTS}

The research was funded by the grant from The Institute for Research, Publication, and Community Service (LP3M) of Muhammadiyah University of Yogyakarta awarded to the first author (SK No:030/PEN-LP3M/I/2020). This research ethics was approved by the ethics commission (KEPK) of the Faculty of Medicine and Health Sciences Muhammadiyah University of Yogyakarta with the number: 36/EC-KEPK FKIK- UMY/I/2020. 


\section{REFERENCES}

[1] APJII.(2017). Penetrasi dan Perilaku Penggunaan Internet Indonesia. Retrievd from https://web.kominfo.go.id/sites/default/files/LaporanSurve yAPJII_2017_v1.3.pdf

[2] Rahayu, F. S. (2012). Cyberbullying Sebagai Dampak Negatif Penggunaan Teknologi Informasi. Jurnal Sistem Informasi, 8(1), 22. https://doi.org/10.21609/jsi.v8i1.321

[3] Natalia, E. C. (2016). Remaja, Media Sosial Dan Cyberbullying. Jurnal Ilmiah Komunikasi, 5, 119-137

[4] Komnas Perempuan.(2016). Catatan Tahunan Tentang Kekerasan Terhadap Perempuan. Retrievd from http://www.komnasperempuan.go.id/lembar-fakta-catatantahunan-catahu-2016-7-maret-2016/

[5] Susanti, R. A. (2018). Hubungan Fungsi Afektif Keluarga dengan Kecerdasan Emosional Remaja [Skripsi]. STIKES Insan Cendekia Medika Jombang

[6] Novrian, A. (2017). Hubungan Antara Fungsi Keluarga dengan Kecendrungan Perilaku Bullying Pada Remaja Muslim Kelas IX Smp Negeri 3 Palembang [Skripsi]. Universitas Islam Negeri Raden Fatah

[7] Rachmatan, R., \& Ayunizar, S. R. (2017). Cyberbullying Pada Remaja SMA di Banda Aceh. Jurnal Insight Fakultas Psikologi Universitas Muhammadiyah Jember, 13(2), 67$79 . \quad$ Retrieved from http://jurnal.unmuhjember.ac.id/index.php/INSIGHT/articl e/view/811

[8] Putri, A. K. N., \& Putra, B. A. (2017). Hubungan Antara Konformitas Terhadap Perilaku Cyberbullying pada Remaja Madya dengan Self-Awareness Sebagai Variabel Moderator. Jurnal Psikologi dan Kepribadian Sosial.

[9] Diananda, A. (2018). Psikologi Remaja dan Permasalahannya. ISTIGHNA, 1(1), 116-133

[10] Wiryada, O. A. B., Martiarini, N., \& Budiningsih, T. E. (2017). Gambaran Cyberbullying pada Remaja Pengguna Jejaring Sosial di SMA Negeri 1 dan SMA Negeri 2 Ungaran. Jurnal Psikologi Ilmiah, 9(1), 18-25. http://journal.unnes.ac.id/nju/index.php/INTUISI

[11] Satalina, D. (2014). Kecenderungan Perilaku Cyberbullying Ditinjau dari Tipe Kepribadian Ekstrovert dan Introvert. Jurnal Ilmiah Psikologi Terapan, 2(2). Retrieved from https://www.bps.go.id/dynamictable/2018/05/18/1337/pers entase-panjang-jalan-tol-yang-beroperasi-menurutoperatornya-2014.html

[12] Sartana, \& Afriyeni, N. (2017). Perundungan Maya (Cyber Bullying) pada Remaja Awal. Jurnal Psikologi Insight, 1(1), 25-39

[13] Ikhsani, S., \& Rakhmawati, N. A. (2016). Hubungan Antara Tingkat Penggunaan Internet Dengan Persepsi Peningkatan Prestasi Pada Pelajar SMA Di Surabaya. Jurnal Tekonologi Dan Sistem Informasi, 2(2), 86-91.

[14] Ismawati. (2018). Karakteristik Ideal Sikap Religiusitas Pada Masa Dewasa. Jurnal At-Tajdid Vol.02 No.01.

[15] Meilasari, A. (2018). Hubungan Antara Keberfungsian Keluarga Dengan Efikasi Diri Pengasuhan Pada Ibu [Skripsi]. Universitas Islam Indonesia

[16] Wang, X., Yang, J., Wang, P., Lei, L.(2019). Childhood Maltreatment, Moral Disengagement, And Adolescents' Cyberbullying Perpetration : Fathers' And Mothers' Moral
Disengagement As Moderators. Computers In Human Behavior 95 48-57. Journal homepage : www.elsevier.com/locate/comphumbeh

[17] Sumakul, B. J. (2015).Peranan Komunikasi Keluarga Dalam Pembentukan Identitas Remaja Di Kelurahan Malalayang I Kecamatan Malalayang Kota Manado. EJournal "Acta Diurna" Volume IV No 4.

[18] Chen Q, Lo CKM, Zhu Y, Cheung A, Chan KL, Ip P. Family poly-victimization and cyberbullying among adolescents in a Chinese school sample. Child Abuse Negl. 2018;77:180-187. doi:10.1016/j.chiabu.2018.01.015

[19] Indrawati, E. S. (2015). Status Sosial Ekonomi Dan Intensitas Komunikasi Keluarga Pada Ibu Rumah Tangga Di Panggung Kidul Semarang Utara. Jurnal Psikologi Undip Vol.14

[20] Jaya, M., \& Pamungkur. (2016). Pengaruh Status Ekonomi Terhadap Prestasi Mahasiswa Perguruan Tinggi Swasta. Jurnal Al-Ulum Ilmu Sosial dan Humaniora Vol.2 No.3

[21] Dewi, E. M. P., \& Basti.(2015). Pengasuhan Ibu Berkarir Dan Internalisasi Nilai Karir Pada Remaja. Jurnal Ilmiah Psikologi Terapan Vol. 03, No. 01.

[22] Fitransyah, R. R., \& Waliyanti, E. (2018). Perilaku Cyberbullying Dengan Media Instagram Pada Remaja Di Yogyakarta. Indonesian Journal Of Nursing Practices Vol. 2 No. 1

[23] Dominguez, C. Y., Franco, M. D. G., \& Hueros, A. D.(2019). Trainee Teachers' Perceptions on Cyberbullying in Educational Contexts. Social Sciences Article

[24] Annisa. (2012). Hubungan Pola Asuh Ibu Dengan Perilaku Bullying Remaja [Skripsi]. Fakultas Ilmu Keperawatan. Universitas Indonesia. Depok.

[25] Abrio, A. R. Leon, C., Ferrer, D.M., \& Gonzalez, M.E.V. (2019). Family Functioning, Self-Concept and Cybervictimization: An Analysis Based on Gender. Social Sciences Article diakses dari https://www.researchgate.net/publication/331278601_Fami ly_Functioning_Self-

Concept_and_Cybervictimization_An_Analysis_Based_on _Gender

[26] Mursafitri, E., Herlina, \& Safri. (2015). Hubungan Fungsi Afektif Keluarga Dengan Perilaku Kenakalan Remaja. Jurnal Keperawatan, Vol 2 No 2(2)

[27] Adawiyah, S. R.(2019). Faktor-Faktor Yang Mempengaruhi Cyberbullying Pada Remaja. Prosiding Seminar Nasional Magister Psikologi Universitas Ahmad Dahlan

[28] You, S., \& Lim, S. A. (2016). Longitudinal Predictors Of Cyberbullying Perpetration: Evidence From Korea Middle School Students. Personality And Individual Differences, 89,172 - 176. https://Doi.Org/10.1016/J.Paid.2015.10.019

[29] Kowalski, R. M., Giumetti, G. W., Schroeder, A. N., \& Lattanner, M. R. (2014). Bullying In The Digital Age: A Critical Review And Meta-Analysis Of Cyberbullying Research Among Youth.Psychological Bulletin,140(4),1073-1137. https:// Doi.Org/ 10.1037/A0035618

[30] Rudyani, M.A., Astuti, I.T., Susanto, H. (2017). Perbedaan Antara Program Full Day School Reguler Terhadap Perkembangan Psikososial Siswa Smp Negeri Di Kecamatan Ngaliyan. Unissula Pres 